\title{
Analysis on the Fraud and Countermeasures of Accounting Computerization
}

\author{
Diao Xuelin \\ (Nanchang Institute of Technology, Nanchang, 330044)
}

Keywords: Accounting computerization; Corporate internal control; Accounting computerized fraud

\begin{abstract}
With the rapid development of China's economy, China's scientific and technological level has been continuously improved, and various new technologies and applications have been continuously developed. In particular, the rise of the Internet information industry has contributed to the rise of New China.As the representative, computerized accounting technology has gradually replaced the original manual bookkeeping method, which greatly liberated people's labor force and enabled people to obtain more benefits, so it has been widely sought after by people.Because of the importance of computerized accounting, accounting fraud has become more and more fraudulent, its harm has become more and more serious, and the losses suffered by companies have become more and more serious. How to prevent accounting computerized fraud has become a general concern for enterprise. By studying the status quo of computerized accounting in China, this paper looks for the reasons and means for the fraud of computerized accounting, and finally finds countermeasures to improve the technical level of computerized accounting in China and promote the development of science and technology and economy in China.
\end{abstract}

\section{Introduction}

After China's reform and opening up, the economy has developed rapidly. Computer network technology has also begun to be widely applied in various fields, making people's lives more convenient and quality.Especially in the field of accounting, the new technology of accounting computerization has been developed. The perfect replacement of manual accounting is a hot pursuit of accounting practitioners and is reflected in all aspects of accounting work.However, the development of accounting computerization technology is very uneven. Although it has been basically popularized in the country, the accounting computerization degree of economically developed urban enterprises is generally higher than that of backward areas. With the promotion and development of accounting computerization throughout the country, the enterprise's accounting information system has undergone a fundamental change, and its work efficiency has improved significantly.However, because accounting computerization is always attached to the network, the security performance of the network will restrict the development of accounting computerization, such as computer virus and network hacking. Therefore, the long-term and stable development of accounting computerization requires the security of the network.

\section{Common Means of Accounting Fraud}

\section{Tamper Input}

The most commonly used method of accounting computerized fraud is to directly tamper with computer input.This is very easy for people who are inadvertently aware of computer program technology.In particular, the act of tampering with input during computerized fraud is relatively simple. It is only relatively easy to achieve the purpose of tampering with data before or after the economic data is entered.

\section{Tamper Documents}

For accounting fraud, documents refer to electronic documents and also to terminal documents.In the process of computerized accounting fraud, people with ulterior motives can modify the file by modifying the relevant terminals in the computer.In the enterprise's specific accounting work, many important data or parameters are often stored as files in the computer. If files 
are maliciously modified or tampered with, it is very easy to create illusions and damage economic data and related documents. Since financial data are usually cumbersome and complicated, such changes are not easily discovered.

\section{Tamper the System Program}

The process of tampering is to achieve fraud through the illegal operation of the program.The important measure to realize accounting computerization is the design of the program. The designer of the program realizes the enterprise's purpose of accounting through the collection, analysis, and processing of data. Some software development and maintenance personnel achieve the fraud of accounting computerization through the program operation of the software.

\section{An Analysis of the Causes of Computerized Accounting Fraud}

\section{Defect of Internal Control System}

The enterprise's management system for accounting computerized files is also not sound and standardized.The relevant accounting records and disk storage information cannot be archived on the one hand, and on the other hand, the content of the archive is not complete even if it has been archived.Therefore, establishing a sound corporate internal control system and standardizing the computerized accounting file management process will effectively reduce the leakage of corporate accounting information and avoid the frequent occurrence of accounting computerized fraud.

\section{Software Defects}

Just talking about accounting-related software, there are hundreds of kinds of today's market, and in these software, there are many problems of security and confidentiality, and there are many defects. Assume that the accounting software used by a company itself has some technical defects, it will give objectively a convenience to fraudsters who want to achieve their own goals through a series of illegal operations, which will lead to accounting frauds, and the phenomenon is getting worse.

\section{Professional Quality and Professional Ethics of Employees}

Corporate financial accounting professionals do not fully understand the relevant accounting computerization knowledge.If the financial professional of a company cannot fully understand the financial software used by the company, and they are not familiar with its operation and application procedures, it will inevitably lead to a one-sided understanding of the software. In the event of a software failure during the operation, the failures will certainly not be eliminated in a timely and effective manner, thus causing a certain loss to the company.

In addition, if corporate accountants can have a certain degree of professional ethics, it will also reduce the incidence of accounting fraud.However, the reality is not as good as it seems. Some employees have always put personal interests above the interests of the company. In order to achieve their goals, they do not hesitate to try their best.

\section{Countermeasures of Accounting Computer Fraud}

\section{Strengthen Inspections of Professional Staffs}

The related work of accounting computerization must rely on computer programs, and enterprises should strictly control the computer program and system security.The company's internal computer systems and procedures are checked and maintained from time to time, and relevant system vulnerabilities that may result in accounting and computer fraud are promptly repaired. This helps to detect as soon as possible the causes of accounting computerized fraud.

\section{Strengthen Internal Control at the Technical Level}

(1) Software Control

In order to avoid the occurrence of accounting fraud, the first thing an enterprise must do is to select an accounting software that meets the national standards and strictly implements the regulations, whether it is developed by their own or purchased from elsewhere.In addition, companies must emphasize physical security, hardware security, software security, and network security in the use of accounting software, and address the major issues of corporate data security 
and confidentiality.Finally, enterprises should also use system conversion, program modification, and other means to prevent fraudulent accounting.

(2) Application Control

First of all, we should realize that the computer's data processing ability is very strong and it runs very fast, so once it goes wrong, like a domino, it will have a huge impact on the subsequent series of data output.Therefore, an enterprise should establish a set of internal control systems that cover all aspects of the company. From the source of the data, strict controls and specifications are used to ensure that the input is correct.

\section{Strengthen Legal Construction at the Legal Level}

At present, the state's provisions on how to dispose of criminal acts using accounting computerization have not yet been clearly introduced.Therefore, in order to reduce the frequency of accounting frauds, it must be clearly defined which actions will violate the law and the related punishment measures after breaking the law.At the same time, the state must also establish relevant legal protections, including information, software, and hardware involved in computerized systems, including whether they are protected and how they are protected.

\section{Conclusion}

At present, the development of China's accounting computerization is still in its infancy, and the problems in accounting computerization are also more prominent. However, it is undeniable that accounting computerization is the development trend of the accounting industry. As practitioners should strengthen the management of accounting computerization and give full play to the application of internal control systems in computerization, accounting personnel should start with themselves so as to make accounting computerization work more accurate and convenient.Only in this way can we provide accurate information for companies to better serve their businesses and prevent fraud.

\section{Acknowledgement}

Fund project: Jiangxi provincial university humanities and social sciences research project(No.GL17215)

\section{References}

[1] Chi F. The accounting computerization environment of shallow financial internal control[J]. Fujian Architecture \& Construction, 2016.

[2] Liu C Y. A Probe into the Internal Control System of Accounting Computerization in Hospital[J]. Enterprise Science \& Technology \& Development, 2010, 31(3):391-3.

[3] Zhang B L. The normal problems and solutions of to carry out small and middle sized enterprises' accounting computerization[J]. Journal of Jiamusi Education Institute, 2012.

[4] Wang S H. An analysis of the effect of task-driven method applied in the teaching of accounting computerization[J]. Journal of Zhangjiakou Vocational \& Technical College, 2011.

[5] Liu W. Internal Control under the Accounting Computerization System[J]. Journal of Lvliang University, 2011.

[6] Zheng C J, Xin-Hua L I. Curriculum Design of "Accounting Computerization Substantive" of the Accounting Profession of Grain Direction[J]. Value Engineering, 2016.

[7] Hao S. The Analysis of Restrictive Factors of Accounting Computerization Implementation[J]. Modern Industrial Economy \&Informationization, 2016.

[8] Qi G, University Y. The application of accounting computerization in small and medium sized enterprises[J]. Journal of Jiamusi Vocational Institute, 2017.

[9] Liu R. The Problems and Countermeasures of Current Accounting Computerization[J]. Journal of Educational Institute of Jilin Province, 2017.

[10] Liang H. On the Talents Cultivation of Accounting Computerization Major under Modern 
Apprenticeship System[J]. Value Engineering, 2017.

[11] Zhang N. Study on Constructing CDIO Model for Curriculum System of Accounting Computerization-Based on Analysis of Accounting Computerization Major at Vocational College[J]. Journal of Tianjin College of Commerce, 2015.

[12] Yang G X. Accounting computerization simulation training laboratory construction and management[J]. Journal of Jiamusi Vocational Institute, 2015. 